\title{
REINTRODUCTION OF ASTACUS ASTACUS L. IN EAST TYROL, AUSTRIA
}

\author{
D. SINT, L. FÜREDER
}

\begin{abstract}
University of Innsbruck, Institute of Zoology and Limnology, Technikerstraße 25, 6020 Innsbruck, Austria.

E-mails: daniela.sint@uibk.ac.at, leopold.fuereder@uibk.ac.at
\end{abstract}

Reçu le 29 janvier 2004

Received January 29,2004

Accepté le 20 août 2004

Accepted August 20, 2004

\begin{abstract}
In Tyrolean like in other European freshwaters, crayfish populations decreased in numbers and qualities. They are today regarded as endangered animals. The Astacus astacus (Linnaeus, 1758) population of historical evidence in Tristacher See and its out flowing stream Tristacher Seebach (mentioned already by Emperor Maximilian I in 1504) became extinct in the late 1990s. After the restoration of the stream we started a species conservation programme with various specific protection measures, including breeding and restocking of young-of-the-year and adult $A$. astacus. Females, after having released their young in the hatchery, were stocked together with males in a 200-m-section of Tristacher Seebach, previously populated by A. astacus. In October, the young-of-theyear crayfish were released in another area of the same stream. To show the importance of habitat diversity and shelter, four sites for introduction were selected describing a gradient of habitat diversity. We monitored general characteristics of the population (sex, size, densities) and compared them to habitat conditions. Individual crayfish were tagged with gloss-paint pens to allow an observation of their movements between the different sections over the summer months. We found significant results when migration behaviour, population assemblage and habitat conditions were compared. Males frequently moved longer distances than females. Migration length corresponded to the gradient of available structures and shelter. Heterogeneous riprap was somewhat preferred to artificial shelter like bricks or plastic tubes. Sections without additional shelter showed almost no presence of crayfish. Sex and size distribution within assemblages appeared also to be affected by habitat conditions. Our results indicate the importance of monitoring in species reintroduction projects, as this research demonstrated the immediate effect and importance of habitat structure and affirmed the success of the protection measures. This may in fact help to avoid future failure.
\end{abstract}

Key-words: Crayfish, conservation, endangered species, habitat, stream ecology.

\section{RÉINTRODUCTION D'ASTACUS ASTACUS L. DANS L'EST DU TYROL, AUTRICHE}

\section{RÉSUMÉ}

Dans le Tyrol comme dans le reste de l'Europe, les populations d'écrevisses diminuent en quantité et en qualité. Aujourd'hui elles sont sur la liste rouge des espèces en danger. La population d'Astacus astacus (Linnaeus, 1758) du lac Tristacher et de 
son affluent Tristacher Seebach (déjà citée dans les annales historiques par l'empereur Maximilian I en 1504) a disparu depuis les années 1990. Après la restauration de la rivière, un programme de conservation des espèces a été lancé comprenant diverses mesures de protection, dont la reproduction et la réintroduction de juvéniles de l'année ainsi que d'adultes. Les femelles, après avoir libéré les jeunes dans l'incubateur, ont été relâchées avec les mâles dans une section de $200 \mathrm{~m}$ de longueur dans Tristacher Seechac autrefois peuplée par $A$. astacus. En octobre, les juvéniles de l'année ont été mis dans une autre section de la rivière. Pour montrer l'importance de la diversité de l'habitat et des abris, quatre sites d'introduction décrivant un gradient de cette diversité ont été sélectionnés. Nous avons surveillé les caractéristiques générales des populations (sexe, taille, densité) et les avons comparées aux conditions d'habitat. Certains individus ont été marqués pour permettre une meilleure observation de leur déplacement entre les différentes sections de la rivière. Les résultats sont significatifs lorsque l'on compare le comportement de migration et l'assemblage de populations aux conditions de l'habitat. Les mâles se déplacent fréquemment sur de plus longues distances que les femelles. La distance de migration correspond au gradient de nombre des structures et des abris. Les milieux hétérogènes dits « riprap " sont sensiblement préférés aux abris artificiels tels que les briques ou les tubes en plastique. Les sections sans abris additionnels ne présentaient aucune écrevisse. Le sexe et la distribution selon la taille dans les assemblages apparaissent être influencés par les conditions de l'habitat. Nos résultats montrent l'importance du suivi dans les projets de réintroduction d'espèce, étant donné que cette recherche a démontré l'effet immédiat et l'importance de la structure de l'habitat et a confirmé le succès des mesures de protection. Ceci peut éviter des échecs dans le futur.

Mots-clés: écrevisse, conservation, espèce en danger, habitat, écologie des rivières.

\section{INTRODUCTION}

Some ten years ago, crayfish were common animals in the brooks and lakes of most European countries, but today they are endangered throughout Europe (e.g. GHERARDI and HOLDICH, 1999; SKURDAL and TAUGBOL, 2001; FÜREDER et al., 2002). By its listing in Annex II of the Habitats Directive of the EU, Austropotamobius pallipes (Lereboullet, 1858 ) is up-valued to a species of community interest whose conservation requires the designation of special areas of conservation (COUNCIL DIRECTIVE 92/43/EEC, ANNEX II). In Tyrol, the two indigenous crayfish species, the stone crayfish Austropotamobius torrentium (Schrank, 1803) and the noble crayfish Astacus astacus are protected by federal legislation (e.g. TYROLEAN FISHERIES LAW 2002) demonstrating their level of threat.

Crayfish are known to play a significant role in freshwater systems. Some species may be used as bioindicators for ecosystem function, although a general applicability is still debated (FÜREDER and REYNOLDS, 2003). Due to their size (largest freshwater invertebrate in Europe) and particular appearance they act as good "flagship species", viable for various aspects in water protection (FÜREDER et al., 2003). Crayfish have also been viewed as ecological engineers, as they are important actors in altering habitat conditions by digging and transferring substrate (STATZNER et al., 2000).

Notwithstanding the so-called "key role" of crayfish in water bodies, they are strongly endangered and often whole populations became extinct. In East Tyrol two of the oldest known populations vanished suddenly in the late 1990s. Tristacher See was already mentioned in 1504 in the "Hunting and Fishing Book" of Emperor Maximilian I holding crayfish (UNTERKIRCHER, 1967). The cause of the extinction a few years ago still remains unclear, since neither a sign of non-indigenous crayfish introduction nor any other identifiable threat is apparent. Only habitat assessments carried out in 2002 resulted in the recording of a few degraded reaches, caused by settlement and land use activities. 
Not only the historic value of this old crayfish site but also the general decrease of crayfish waters in our region, gave rise to a proposal for a species protection plan. As part of it, a project was started in 2001 with the objective of improving the habitat for $A$. astacus and to give an estimate of its suitability and the potential effect of habitat conditions on the reintroduced population.

In this paper we focused on the following questions:

- Is the reintroduction of $A$. astacus in Tristacher Seebach successful; do habitat and stocking material match?

- How do the adult crayfish behave (migrate) after release and does their behaviour change with time and season?

- Is it possible to reduce a potential migration tendency by offering higher densities of shelter?

- Do sex and size affect the choice of the place of residence?

\section{MATERIAL AND METHODS}

\section{Investigation area}

Tristacher Seebach is a small outlet of Tristacher See, draining forest and pasture before it flows into the river Drau (Figure 1). Both, lake and stream are situated in the submontane vegetation zone of the Lienzer Dolomiten, a mountain massif in East Tyrol. The catchment is mostly influenced by calcareous rock (limestone). Nikolsdorfer Weiher, the source of the crayfish stocking population, is a quarry pond near the river Drau within the same catchment.

\section{Breeding and stocking}

Since the population became extinct in the 1990s, another population of $A$. astacus from the same catchment was selected as a source for breeding and restocking. Nikolsdorfer Weiher was known to hold the only other noble crayfish population in East Tyrol. The assumption that this pond was probably founded with individuals from Tristacher See or its out flowing Seebach is based upon the vicinity of the two locations within the same catchment. This further implies that the source population is adapted to local climate conditions, which may be important for a successful restocking.

In May 2002, 17 female crayfish were caught by hand in Nikolsdorfer Weiher (source population of $A$. astacus). The egg carrying females were brought to a crayfish hatchery in Göstling (Lower Austria) and returned to East Tyrol after releasing their young in July. The young-of-the-year were kept in the hatchery over summer and then brought to Tristacher Seebach. They were stocked in two different areas where restoration measures had been applied earlier. Without any discontinuities, all released crayfish were able to migrate freely between the different sections of Tristacher Seebach.

\section{Experiments of habitat suitability}

On July $25^{\text {th }}, 63$ crayfish (i.e., the already captured females with additional individuals from Nikolsdorfer Weiher, all together 42 females and 21 males), were measured (claw length and width, carapace length and width, total length) and weighed. Each animal was marked with a gloss-paint pen by writing a number on the carapace. We used different colours to allow subsequent individual identification without re-catching (Figure 2). With this method, unnecessary disturbance by handling was reduced. The only disadvantage was the restricted observation period, caused by lost markings due to moulting or abrasion. 


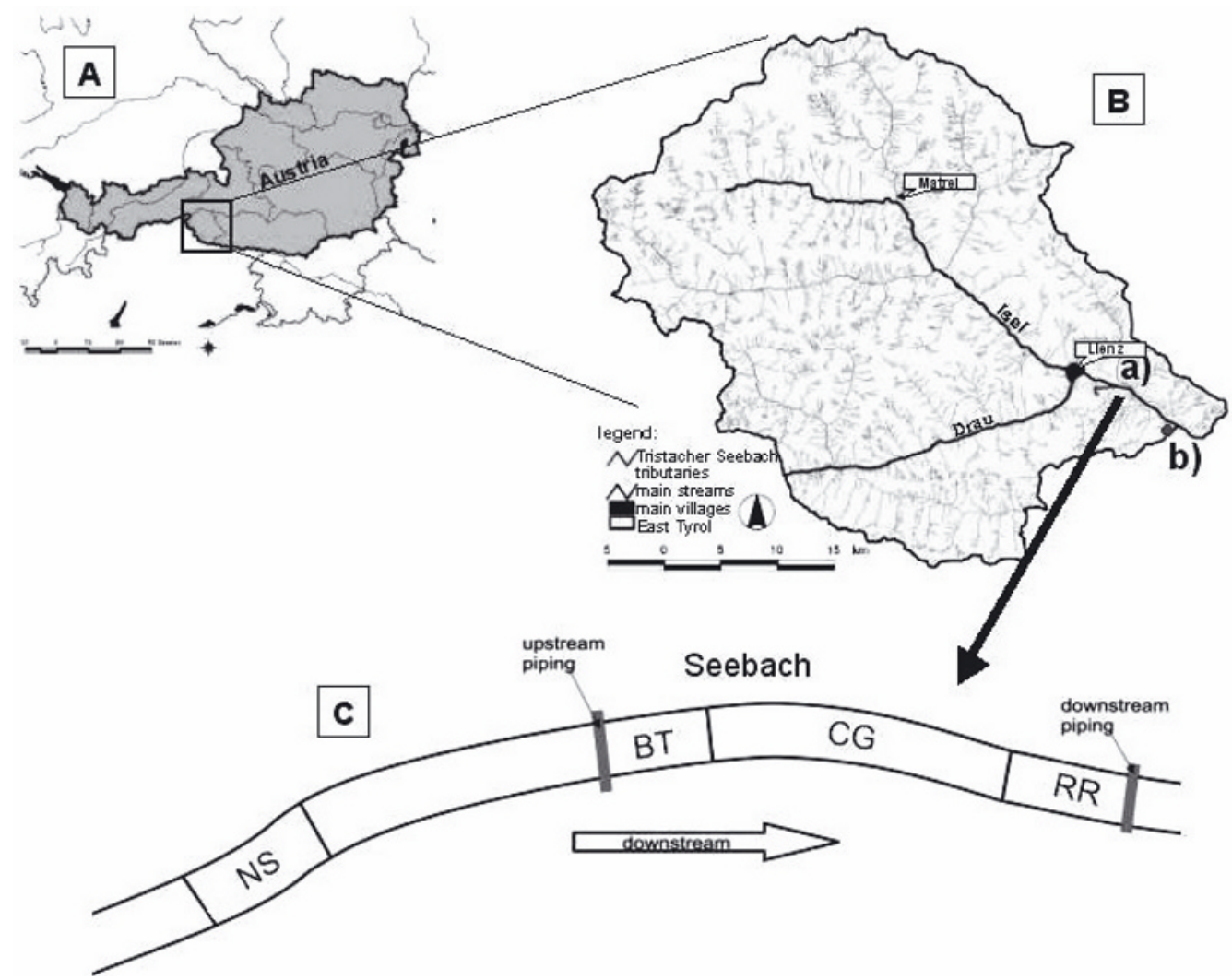

Figure 1

Location of the investigation area. (A) Location of East Tyrol in Austria, (B) Overview East Tyrol, a) Tristacher Seebach, b) Nikolsdorfer Weiher (origin of the stocked crayfish); (basic data: TIRIS), (C) Detail of the experimental area in Tristacher Seebach, $\mathbf{R R}=$ riprap, $B T=$ bricks and tubes, $\mathbf{C G}=$ cages, $\mathbf{N S}=$ no additional shelter (Maps: Mag. Dr. Claude M.E. Hansen MAS $_{\mathrm{GIS}}$ ).

Figure 1

Site de l'expérience. (A) Vue de l'Est du Tyrol en Autriche, (B) vue d'ensemble de l'Est du Tyrol a) Tristacher Seebach, b) Nikolsdorfer Weiher (origine des écrevisses réintroduites) ; (base de données: TIRIS), (C) Détail des sections expérimentales dans le Tristacher Seebach, $R R=$ riprap, $B T=$ briques et tubes, $C G=$ cages, NS = pas d'abris supplémentaires Cartes: Mag. Dr. Claude M.E. Hansen MAS $_{\text {GIS }}$ ).

\section{Habitat use and migration experiment}

To find out, if the availability of a high density of shelter could prevent the migration of the crayfish after the introduction, we altered parts of Tristacher Seebach. An area of about 200 meters length was divided into four sections (Figure 1C). To three of them we added artificial structures, in order to create a gradient of shelter quality and density. We used rocks to form a riprap (experimental site RR), featuring the highest density of hiding places. About one hundred meters upstream, bricks and tubes of different diameter were exposed to create a section with appropriate shelter (experimental site BT), but still providing less than the riprap area. Between RR and BT, a section with enclosures for another experiment (not treated in this paper), also equipped with tubes and bricks, offered additional structures but in rather low densities (experimental site CG). The fourth section was the untreated area and lay another hundred meters upstream. It was not changed in 


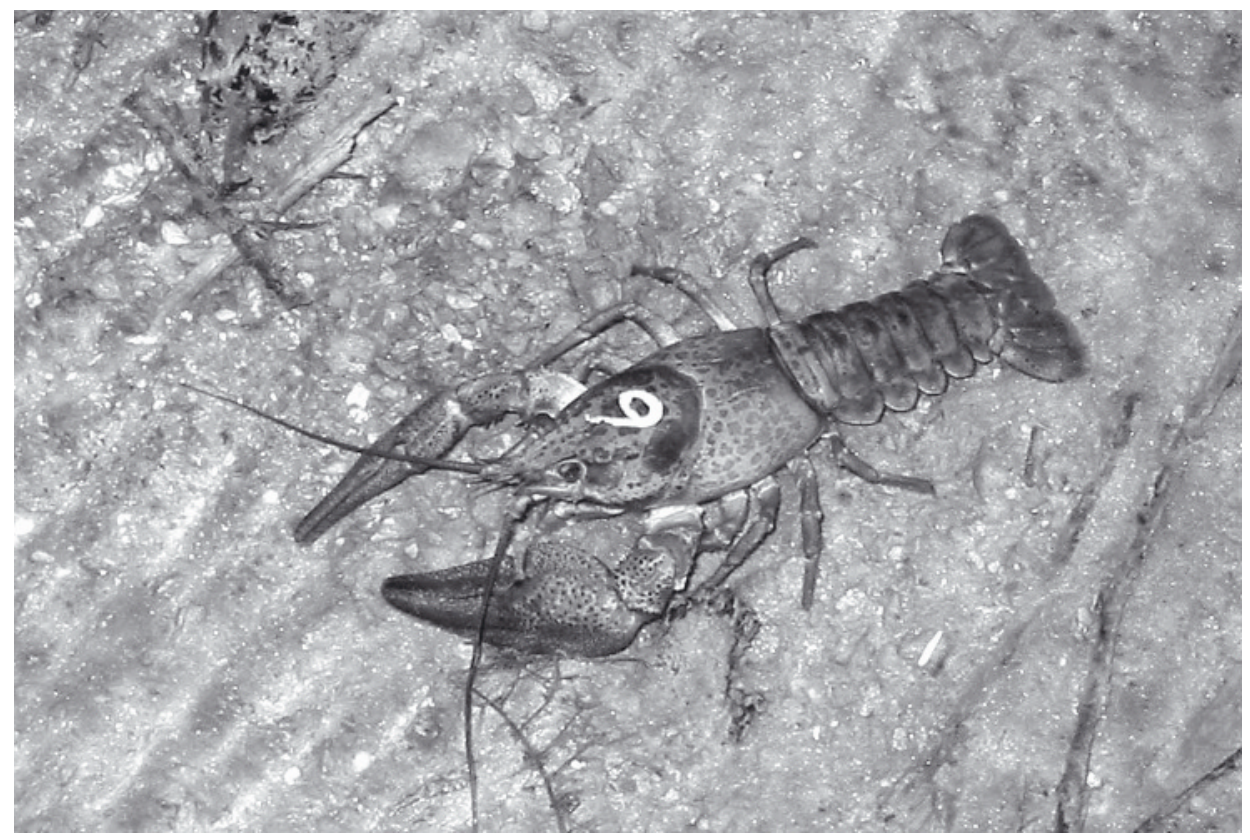

Figure 2

Astacus astacus (marked with dye) after releasing in Tristacher Seebach. (photo: D. Sint).

\section{Figure 2}

Astacus astacus (marqué avec couleur) après réintroduction dans le Tristacher Seebach. (photo : D. Sint).

any way, but did not provide shelter for crayfish (study site NS). The two channel pipings supporting small bridges across the stream were about $1 \mathrm{~m}$ in diameter. The water level was deep enough throughout the year to enable free migration of crayfish, which could be observed in both directions several times.

\section{Crayfish observations}

In order to estimate the importance of shelter for the colonisation of water bodies through noble crayfish, repeated observations took place every second or third day between July $26^{\text {th }}$ and August $9^{\text {th }}$, afterwards on a weekly basis until October $26^{\text {th }}$, 2002, when activities declined significantly. While walking on a defined route along the brook every time a crayfish was seen its number was noted together with date, time and place. Later in summer and autumn, when some of the markings had been lost, it was only possible to notice that a crayfish was seen at a certain place but not exactly which individual.

\section{Temperature}

Temperature was monitored from June $21^{\text {st }}$ until November $16^{\text {th }}, 2002$ with data loggers (Optic StowAway ${ }^{\circledR}$ Temp, ONSET Computer Corporation, MA, U.S.A.).

\section{Statistics}

All data were analysed using Microsoft Excel and Sigma Plot 8.0. Statistics, calculations of One-Way ANOVA and following pair wise multiple comparison procedures (Holm-Sidak method) to detect significant differences between treatments, were done with Sigma Stat 3.0. 
Table I gives a review of the above explained experimental activities.

\section{Table I}

Timetable of activities during the study.

Table I

Horaire des activités du projet

\begin{tabular}{ll}
\hline Date & Activity \\
\hline $21.06 .-16.11 .02$ & registration of temperature in Tristacher Seebach \\
21.05 .02 & capture of females in Tristacher Seebach and transfer to hatchery \\
26.07 .02 & return of females and releasing crayfish to Tristacher Seebach \\
$26.07 .-26.10 .02$ & observing crayfish in Tristacher Seebach \\
25.10 .02 & measuring of young crayfish in the hatchery and transfer to Tristach \\
26.10 .02 & releasing young crayfish to Tristacher Seebach \\
\hline
\end{tabular}

\section{RESULTS}

\section{Breeding}

Altogether the 17 females carried about 1500 eggs, of which a number of 507 young-of-the-year crayfish were transferred to Tristacher Seebach at the end of summer. During the hatching period, our monitoring resulted in a clear relationship between individual densities and the growth of the young crayfish. At similar temperatures, crayfish were bigger, heavier and less injured with decreasing density (Table II).

\section{Table II}

One way ANOVA of total length (TL), weight and number of injuries (measured as missing legs and/or claws) dependent on the densities of young crayfish (YC) in the different basins. Values for total length and injuries are means out of 100 randomly chosen individuals from each basin. The mean weight is given for eight randomly chosen groups of 10 individuals from each basin. Significance indicates differences between densities

\section{Table II}

One way ANOVA' de la longueur totale (TL), du poids et du nombre des blessures (mesurées par les pattes et les pinces manquantes) dépendant des densités de juvéniles (YC) dans les différents bassins. Les valeurs pour la longueur totale et les blessures sont des moyennes pour 100 individus choisis au hasard dans chaque bassin. Le poids moyen est indiqué pour huit groupes pris au hasard dans chaque bassin, de 10 individus chacun. Significance indique les niveaux significatifs entres les densités

\begin{tabular}{lcccc}
\hline $\begin{array}{l}\text { Density of } \\
\text { young crayfish } \\
\text { (Ind. } \mathbf{~ m}^{-2} \text { ) }\end{array}$ & 43.6 & 65.6 & 93.6 & Significance \\
\hline $\begin{array}{l}\text { TL }(\mathbf{m m}) \\
\text { Weight }\end{array}$ & 23.1 & 22.2 & 21.0 & $\mathrm{p}<0.001$ \\
$\begin{array}{l}\text { (g per } \mathbf{1 0} \text { YC) } \\
\text { Injuries }\end{array}$ & 3.73 & 2.93 & 2.34 & $\mathrm{p} \leq 0.001$ \\
\hline
\end{tabular}




\section{Crayfish Activity}

Crayfish activity was clearly higher at the end of July and on the first days of August as compared to the rest of the observation period. It followed generally the temperature pattern, a decrease was noticeable with declining temperature and was strongest when temperature fell below $10^{\circ} \mathrm{C}$ (Figure 3).

Between July $26^{\text {th }}$ and August $9^{\text {th }}$, the average number of observed crayfish per evening was 24, whereas it decreased to an average of 13 individuals from mid August until September. Mid September ( $13^{\text {th }}$ and $\left.19^{\text {th }}\right)$ we monitored a temporary increase of crayfish activity as we observed 18 and 16 individuals. Thereafter the activity level decreased again and we found an average of 5.5 individuals per night. Finally from mid September until the end of October the number of observed individuals continuously declined from 11 to 1 and 3 individuals respectively (Figure 3).

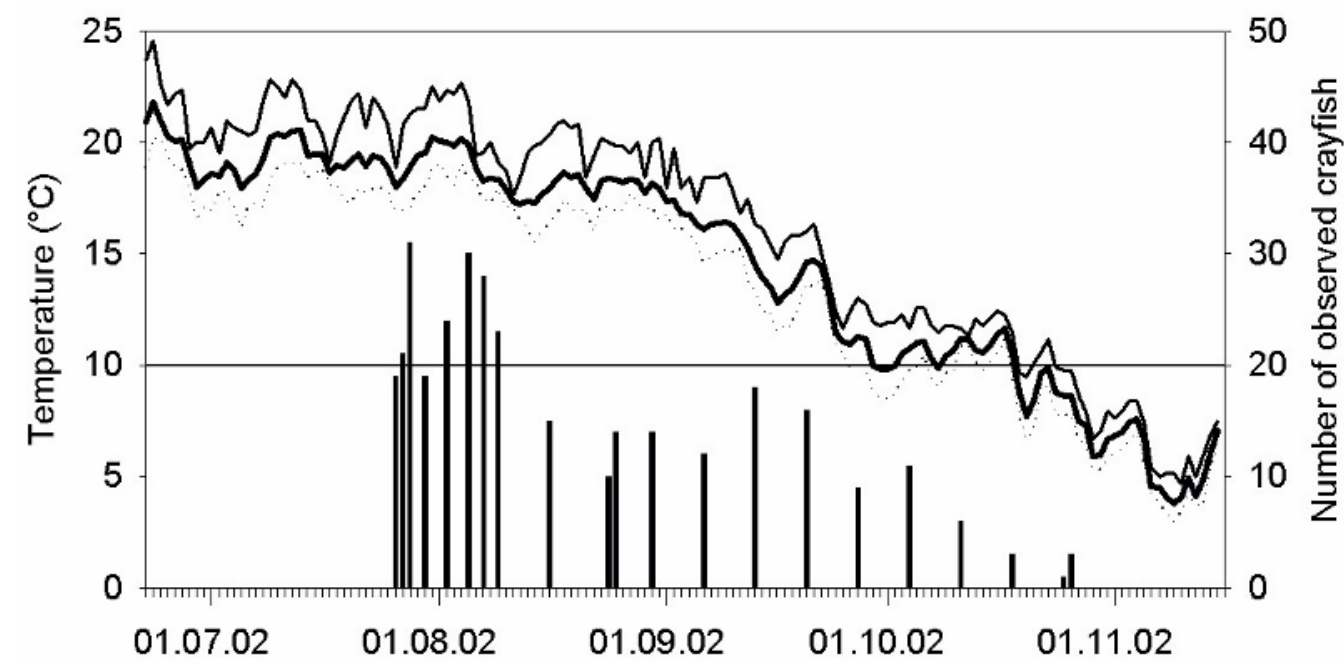

Figure 3

Crayfish and temperature. The number of observed crayfish per night in Tristacher Seebach (after the introduction on July $26^{\text {th }}$ ) is shown as bars and the water temperature as lines. The thick line is the daily mean, the thin line the highest daily temperature and the dotted line is the lowest daily temperature.

\section{Figure 3}

Ecrevisses et températures. Le nombre des écrevisses observées par nuit dans le Tristacher Seebach (après l'introduction du 26 juillet 2003) est indiqué par des barres et la température de l'eau par des lignes. La ligne épaisse indique les moyennes journalières. La ligne mince et la ligne pointillée représentent le maximum et le minimum respectivement des températures de chaque jour.

Means of observed crayfish per running meter over summer differed from stocking densities - which are the numbers of stocked crayfish per meter in July - at all sites (Figure 4). Highest numbers with 0.26 crayfish per meter were noticed at site RR, followed by 0.19 at BT and 0.11 at CG. In the section without additional shelter only 0.01 crayfish per meter were observed. Also maximum numbers declined with decreasing availability of shelter, being highest at RR with 1.07 crayfish per meter and decreased to 0.13 at NS. On a temporal pattern the records decreased further at RR, BT, and CG, as the activities generally decreased in autumn. A fact which is not relevant for section NS since crayfish avoided this area from August onward. 
When the results of the observations during summer from the different sections were compared, NS differed very highly significantly $(p<0.001)$ from the two sites with highest densities of structures (RR and BT) and still significantly $(p<0.05)$ from CG. Mean crayfish observed in $C G$ are highly significantly lower $(p<0.01)$ than in RR. The average from site BT were not significantly different from either RR or CG $(p>0.05)$.

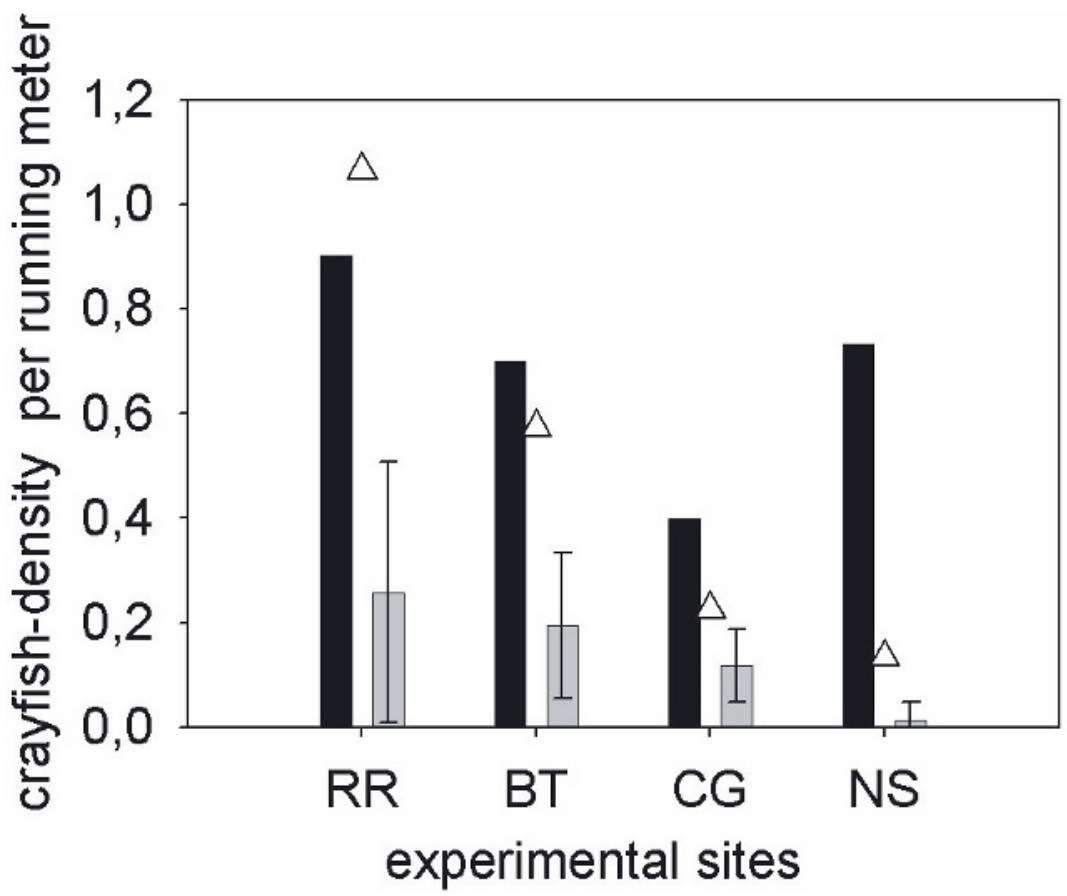

Figure 4

Comparison between stocking density (stocked crayfish per meter in July; black columns) and means of the observed crayfish densities per meter and per evening (grey columns with standard deviation) at the different sites. Triangles show the highest observed crayfish densities. $R R=$ riprap, $B T=$ bricks and tubes, CG $=$ cages, $\mathbf{N S}=$ no additional shelter.

\section{Figure 4}

Comparaison entre la densité de stockage (écrevisses introduites par mètre en juillet ; colonnes noires) et la moyenne de la densité des écrevisses observées par mètre et par soir (colonne grise avec déviation standard) des différents sites. Les triangles déterminent la densité maximale observée d'écrevisses. $R R=$ riprap, BT = briques et tubes, $C G$ = cages, NS = pas d'abris supplémentaires.

The post-release migration pattern also differed when individual experimental sites were compared. Crayfish released at sites with a higher density of shelter moved shorter distances and overall migrations increased with declining shelter densities. Crayfish stocked in the area without additional shelter (NS) covered by far the longest distances. Usually males moved longer distances than females (e.g. 194.8 vs. $102.3 \mathrm{~m}$ at NS; 60.3 vs. $37.0 \mathrm{~m}$ at $\mathrm{CG}$ ). Distances were only somewhat shorter in the section with bricks and tubes (BT), where males migrated $58.8 \mathrm{~m}$ and females $24.8 \mathrm{~m}$. The mean migration distance of males was lowest in the section RR $(2.5 \mathrm{~m})$ and this was also the only section where females $(41.4 \mathrm{~m})$ moved longer distances than the males (Table III, Figure 5). 
Table III

Differences in the averages of the migration distances between the different crayfish groups according to their sex and the place of their introduction (RR - riprap, BT - bricks and tubes, CG - cages, NS - no additional shelter; $(m)=$ males, $(f)=$ females). Significance levels: ${ }^{* *}=p<0.001 ;{ }^{* *}=p<0.01$; ${ }^{*}=\mathrm{p}<0.05 ;$ n.s. $=$ no significant difference

Table III

Différences entre les distances moyennes de migration entre les différents groupes d'écrevisses selon leur sexe et l'endroit de leur introduction (RR = riprap, BT = briques et tubes, $C G$ = cages, $N S$ = pas d'abris supplémentaires; $(\mathrm{m})=$ mâles, (f) $=$ femelles). Niveau significatif: ${ }^{* * *}=p<0.001 ;{ }^{* *}=p<0.01 ;{ }^{*}=p<0.05$; n.s. = pas de différence significative.

\begin{tabular}{|c|c|c|c|c|c|c|c|}
\hline & NS (m) & NS (f) & CG (m) & CG (f) & BT (m) & BT (f) & RR (m) \\
\hline$R R(f)$ & $* \star \star$ & * & n.s. & n.s. & n.s. & n.s. & n.s. \\
\hline $\mathrm{RR}(\mathrm{m})$ & $\star \star \star ~$ & ** & n.s. & n.s. & n.s. & n.s. & \\
\hline BT (f) & $* * *$ & ** & n.s. & n.s. & n.s. & & \\
\hline BT (m) & $\star \star \star ~$ & n.s. & n.s. & n.s. & & & \\
\hline$C G(f)$ & $* * *$ & ** & n.s. & & & & \\
\hline CG (m) & $\star \star \star *$ & * & & & & & \\
\hline NS (f) & ** & & & & & & \\
\hline
\end{tabular}

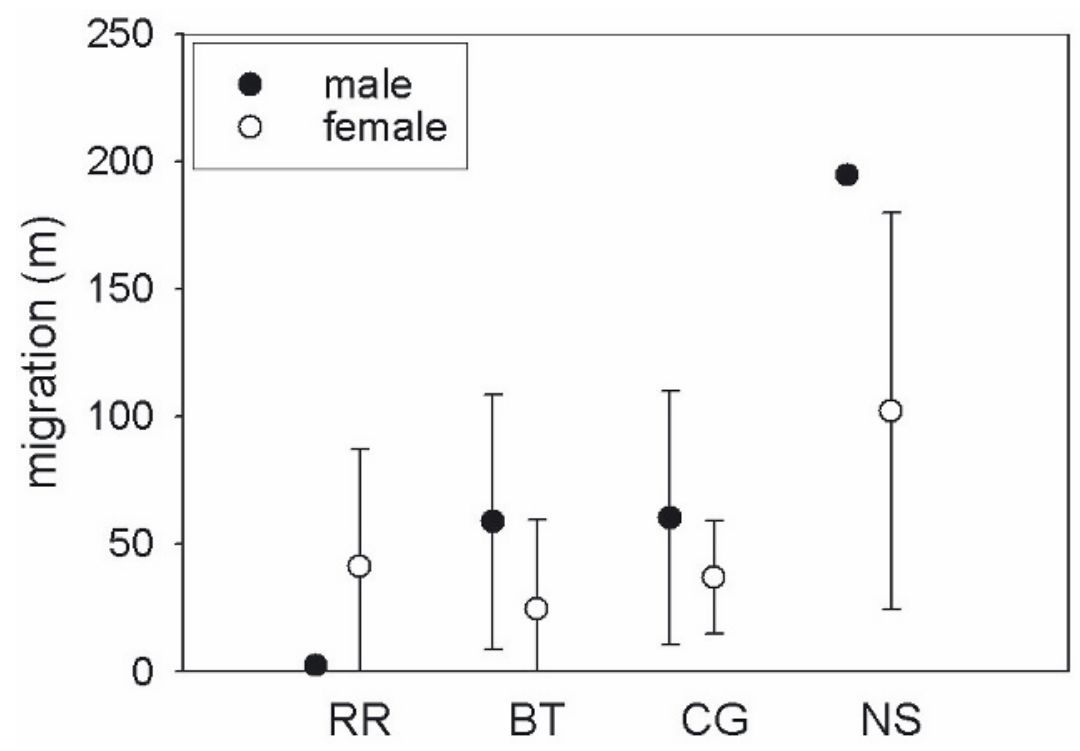

Figure 5

Mean and standard deviation of crayfish migration after release according to site and sex. $\mathrm{RR}=$ riprap, $\mathrm{BT}=$ bricks and tubes, $\mathrm{CG}=$ cages, $\mathrm{NS}=$ no additional shelter. (Note: all points are an average of several individuals).

\section{Figure 5}

Moyenne et déviation standard des migrations des écrevisses après introduction, selon le site et le sexe. $R R=$ riprap, $B T=$ briques et tubes, $C G=$ cages, $N S=$ pas d'abris supplémentaires. (note: tous les points représentent une moyenne de plusieurs individus). 
During the first weeks of the experiment (from July to mid of August) the crayfish grouped themselves by sex and size. At the onset of the study the mean total length at site RR was about $100 \mathrm{~mm}$ for males as well as for females. During the experiment (until August $16^{\text {th }}$ ), the mean size changed to $115 \mathrm{~mm}$ in males and to $97 \mathrm{~mm}$ in females. The opposite was observed at BT. Here, the mean total length of females shifted from 102 to $107 \mathrm{~mm}$, while the mean size of males remained at $93 \mathrm{~mm}$. Fluctuations in this pattern could be observed due to a high migration activity of some individuals. For example, crayfish "Yellow 6", a male with a total length of $133 \mathrm{~mm}$, increased the mean at BT, but was seen some days later at RR near the other large males. The experimental site CG, situated between RR and BT, was assumed to be especially influenced by migrating crayfish, showed also some separation (compare with Figure 6). For section NS it is hardly possible to derive tangible results as we observed crayfish on only three days.

Unfortunately it was only feasible to itemise the data in that way only until mid August. Thereafter it was nearly impossible to identify the individuals, as most of the markings were lost due to moulting or abrasion.
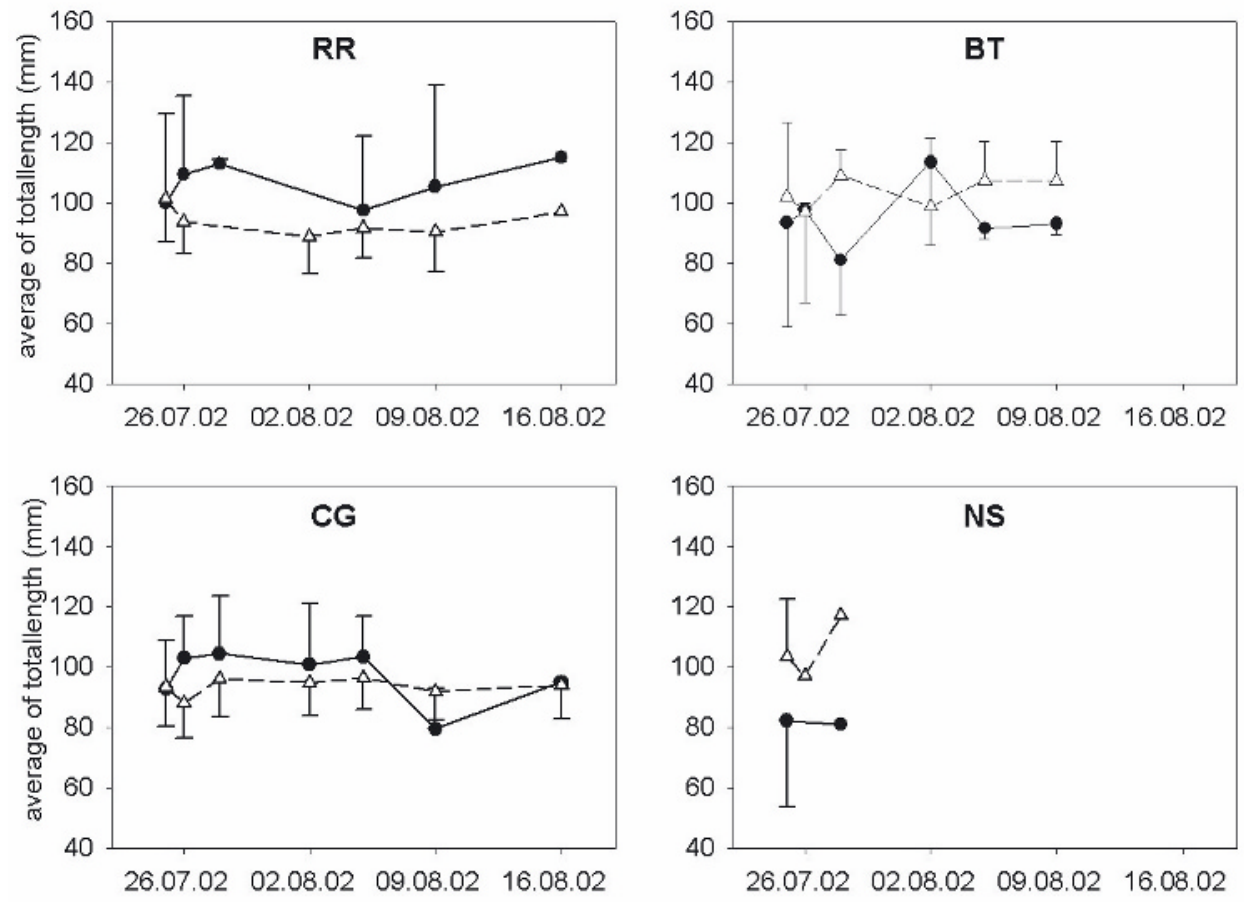

Figure 6

Total length distribution of male (black symbols) and female (white symbols) crayfish in the first three weeks after release. RR = riprap, BT = bricks and tubes, CG $=$ cages, $N S=$ no additional shelter. The missing data for August $16^{\text {th }}$ in section BT indicate missing markings due to moulting and abrasion. At site NS, the missing data are due to a total absence of crayfish in this area after July $28^{\text {th }}$.

\section{Figure 6}

Distribution de la longueur totale des mâles (symboles noirs) et des femelles (symboles blancs) pendant les trois semaines après introduction. RR = riprap, BT = briques et tubes, $\mathbf{C G}=$ cages, $\mathbf{N S}=$ pas d'abris supplémentaires. Les valeurs du 16 août 2003 de la section BT sont manquantes à cause de la mue et de l'abrasion. Les valeurs manquantes au site NS résultent de l'absence totale d'écrevisse dans cette aire après le 28 juillet. 


\section{DISCUSSION}

Several studies are now available which demonstrate a continued decline of indigenous crayfish populations in European freshwaters (e.g. GHERARDI and HOLDICH, 1999; SKURDAL and TAUGBOL, 2001; FÜREDER et al., 2002). In Austria the situation is similar: native species are regarded as endangered (GEPP, 1994). Habitat degradation, land-use activities, and the introduction of exotic species have been cited frequently as liable reasons for this decline (GHERARDI and HOLDICH, 1999; FÜREDER and HANEL, 2000; FÜREDER et al., 2002). In several countries species protection plans were designed to improve the situation of native crayfish. Among others, species (re-) introduction was suggested as a conservation measure (e.g. REYNOLDS and MATTHEWS, 1997; FÜREDER and HANEL, 2000; FÜREDER et al., 2002). However, little is known about the success of introductions and even less is known about the post-release behaviour and migration of crayfish.

This publication reported on the reintroduction of Astacus astacus to a crayfish habitat of special historical value. Being one of the three oldest records of crayfish in Tyrol a re-naturalisation of this crayfish habitat was considered extremely important. It prompted us to monitor reintroduced crayfish and to investigate habitat suitability and the potential effect of habitat conditions on the reintroduced population.

\section{Breeding}

Temperature, food supply and shelter were kept similar in the individual raising tanks, the only notable difference was crayfish density. In tanks with less dense populations the number of injuries was lower and these fewer individuals showed better growth (length and biomass). VERHOEF and AUSTIN (1999a) found that the density had an influence on the growth but not on the survival rate of crayfish. In another study, the same authors assumed that the availability of shelter was the most important factor (VERHOEF and AUSTIN, 1999b). Our results show that survival is not influenced by the availability of shelter, since plenty of hiding possibilities were provided in the individual tanks. Density related factors appeared to be the main cause. NELSON and HEDGECOCK (1983) showed, that factors such as growth inhibition due to release of chemical substances might be responsible for lower growth.

Whatever the factors influencing growth and development, a fast growth rate is essential for the success of reintroduction measures. The are chance of survival of young crayfish released in autumn depends often on their size because predation risk from fish decreases with increasing body length (ENGLUND and KRUPA, 2000). Thus, reduction of crayfish densities in breeding tanks may help to improve the success of reintroductions.

\section{Post-stocking activities}

Our results showed that the general temporal patterns in crayfish activities corresponded well to the temperature. After an initially higher activity during the first days, caused presumably by handling stress from catch, transport, mark and release of individuals, crayfish activity followed the general pattern of water temperature. A temporary decrease of activities at the end of July and beginning of August might have been caused by moulting females, which did not moult before the introduction. Males did not moult until September, when another slight decrease in activity was registered. These moulting periods could be confirmed by the presence of marked exuvia and are also known from the literature (ACKEFORS, 1999, STUCKI, 1999).

The increased activity in the middle of September was due to the onset of mating and was followed by a general decrease caused by the disappearance of females. With the decline of the minimum temperature below $10^{\circ} \mathrm{C}$, females are known to eject the eggs 
and hide for overwintering (ACKEFORS, 1999, STUCKI, 1999, HOLDICH, 2003). This was also confirmed by the capture of single males and still unfertilised females at that time.

The importance of channel morphology and habitat availability was demonstrated in a few studies (HUOLILA et al., 1997, SCHULZ and KIRCHLEHNER, 1984, SMITH et al., 1996). SCHULZ and KIRCHLEHNER (1984) found a positive correlation between the abundance of $A$. torrentium and the number of stones and wood, which could serve as shelter. Furthermore they found a negative correlation between the occurrence of the stone crayfish and the frequency of muddy and sandy sediment in a little brook. SMITH et al. (1996) also found a correlation between the availability of structures at the river bank (presence of shrubs and trees and the extension of their roots into the water) and the abundance of $A$. pallipes. The results of HUOLILA et al. (1997) were similar to those of this study. They released marked $A$. astacus to a partly altered brook and after one year they caught the highest number of crayfish at the section with broken rock as additional shelter. Unlike the present study, they found also crayfish in the untreated sections. Maybe this was due to the fact that young crayfish (they reported a mean carapace length of $42.6 \mathrm{~mm}$ ) usually migrate less than adults.

Also our study strongly confirmed these results. The gradient of shelter quality and quantity in our experimental design had a strong influence on crayfish densities. Despite some larger standard deviations, caused by calculating the mean over the whole investigation period, crayfish activity decreased clearly and the individual sites differed significantly. The correlation was very significant when the maximal densities (triangles in Figure 3 ) at the different sites were compared to each other.

In our experiment the availability of shelter was also related to the distance covered by crayfish after the introduction. Longer migration distances coincided with less available structure. Individual residence time was longer in sections that offered more shelter. Migration was not affected by the possibility of burrowing offered by the banks.

In general males moved longer distances than females, except at site RR, where bigger males became more territorial. Once arrived, they generally stayed at this site. Consequently, they obviously raised the pressure on females to emigrate. This would explain the greater migration of females released at this site. Territorial aspects might also have been the reason why the larger males were grouped with the younger females at RR, and the larger females at BT with smaller males. STREISSL and HÖDL (2002) found for males of $A$. torrentium a correlation of body size and shelter size. A similar coherence is also possible for $A$. astacus. Sex-size distribution in the section with less attractive shelter was less distinct. A similar distribution pattern was found during the capture of egg-carrying females in May 2002 in Nikolsdorfer Weiher, where areas with adult males alternated with areas populated by females and juveniles.

Our results indicated that a variety and a certain amount of shelter have to be provided in reintroduction projects. Enough shelter has to be available in more than only one area. Furthermore it is an advantage if the structures are heterogeneous so that every crayfish is able to find a fitting hiding place.

The addition of untypical structures (like riprap in a forest stream) to improve the habitat can have positive effects but is not a general recommendation for all reintroduction projects. In the present study it was necessary for the experimental design, but it was nevertheless an artificial change of ecosystem properties. Stream type and specific habitat conditions should be considered.

The results of our field experiments demonstrated that the success of crayfish (re-) introductions might be enhanced with simple measures. With optimal habitat conditions one can make sure that the animals come across appropriate shelter immediately after stocking. These measures, in this study, reduced migration of crayfish, which is considered 
a problem after introduction into a new habitat. Hence, the combined stocking with adults out of a dense population and with juveniles can be more successful. At the same time, it may also be a good method to restore "dwarf populations" because the withdrawal of adult crayfish is known to cause positive effects on growth and population structure in the source population (KELLER, 1999).

The ever decreasing number of autochthonous crayfish populations in many European regions underlines the importance of ecological knowledge for planned reintroductions. The loss of populations due to crayfish plague but also to environmental degradation (land use, water regulation) call for an immediate reaction to prevent further loss of indigenous crayfish. Reintroduction can be a successful measure if it takes place within the context of a well defined programme. An optimal and promising implementation needs fundamental knowledge such as the behaviour of (re-) stocked crayfish in the new habitat. In this sense, this study brought important results but may also help to pose new questions.

\section{ACKNOWLEDGEMENTS}

The support of the Fischereiverband Nikolsdorfer Weiher for their friendly surrender of crayfish for the introduction measures is appreciated. We also thank the mayor of Tristach Ing. Alois Walder, as well as DI Walter Hopfgartner and Ing. Georg Hofmann from the Baubezirksamt Lienz, and the Bundesministerium für Land- und Forstwirtschaft, Umwelt und Wasserwirtschaft for providing essential help and financial support and Mag. Dr. Claude Hansen $\mathrm{MAS}_{\mathrm{GIS}}$ for the French translation.

\section{REFERENCES}

ACKEFORS H.E.G., 1999. Observations on the Yearly Life Cycle of Astacus astacus in a Small Lake in Sweden. Freshwater Crayfish, 12, 413-429.

COUNCIL DIRECTIVE 92/43/EEC of 21 May 1992 on the conservation of natural habitats and of wild fauna and flora, Annex II.

ENGLUND G., KRUPA J.J., 2000. Habitat use by crayfish in stream pools: influence of predators, depth and body size. Freshwater Biology, 43, 75-83.

FÜREDER L., HANEL R., 2000. Flusskrebse in den Gewässern Nord- und Osttirols: Verbreitung, ökologische Bedeutung und Schutzmaßnahmen. Berichte des naturwissenschaftlich-medizinischen Vereins in Innsbruck, 87, 221-241.

FÜREDER L., OBERKOFLER B., HANEL R., MACHINO Y., 2002. Freshwater crayfish in South Tyrol (Italy): Distribution and protection measures of endangered Austropotamobius pallipes. Bull. Fr. Pêche Piscic., 367, 651-662.

FÜREDER L., OBERKOFLER B., LEITER J., THALER B., 2003. Austropotamobius pallipes in South Tyrol: heritage species and bioindicator. Bull. Fr. Pêche Piscic., 370-371, 81-96.

FÜREDER L., REYNOLDS J., 2003. Is Austropotamobius pallipes a good bioindicator? Bull. Fr. Pêche Piscic, 370-371, 157-163.

GEPP J., 1994. Rote Listen gefährdeter Tiere Österreichs. Grüne Reihe des Bundesministeriums für Umwelt, Jugend und Familie, Band 2: 355 pp.

GHERARDI F., HOLDICH D.M., 1999. Crayfish in Europe as alien species. How to make the best of a bad situation. Crustacean Issues 11, A.A. Balkema, Rotterdam, Brookfield, pp. 1-299. 
HUOLILA M., MARJOMÄKI T.J., LAUKKANEN E., 1997. The success of crayfish stocking in a dredged river with and without artificial shelter increase. Fisheries Research, 32, 185-189.

HOLDICH D.M., 2003. Ecology of the White-clawed Crayfish. Conserving Natura 200 Rivers Ecology Series No. I. English Nature, Peterborough.

KELLER M., 1999. Ten Years of Trapping Astacus astacus for Restocking in Lake Bronnen, a Gravel Pit in Bavaria. Freshwater Crayfish, 12, 518-528.

NELSON K., HEDGECOCK D., 1983. Size-dependence of growth inhibition among juvenile lobsters (Homarus). Journal of Experimental Marine Biology and Ecology, 66 (2), 125-134.

REYNOLDS J.D., MATTHEWS M., 1997. Successful reintroduction of crayfish to Irish lake. Crayfish News-IAA Newsletter, 19 (2), 4-5.

SCHULZ N., KIRCHLEHNER W., 1984. Der Steinkrebs Bestand Austropotamobius torrentium (Schrank) im Spintikbach (Kärnten, Österreich). Österreichs Fischerei, 37, 47-57.

SKURDAL J., TAUGBOL T., 2001. Crayfish of commercial importance. Astacus. In: HOLDICH D.M., (Ed.), Biology of freshwater crayfish. Blackwell Science, Oxford, pp. 467-510.

SMITH G.R.T., LEARNER M.A., SLATER F.M., FOSTER J., 1996. Habitat features important for the conservation of the native crayfish Austropotamobius pallipes in Britain. Biological Conservation, 75, 239-246.

STATZNER B., FIÈVET E., CHAMPAGNE J.Y., MOREL R., HEROUIN E., 2000. Crayfish as geomorphic agents and ecosystem engineers: Biological behaviour affects sand and gravel erosion in experimental streams. Journal of Limnology and Oceanography, 45 (5), 1030-1040.

STREISSL F., HÖDL W., 2002. Habitat and shelter requirements of the stone crayfish Austropotamobius torrentium Schrank. Hydrobiologia, 477, 195-199.

STUCKI T.P., 1999. Life Cycle and Life History of Astacus leptodactylus in Chatzensee Pond (Zürich) and Lakr Ägeri, Switzerland. Freshwater Crayfish, 12, 430-448.

TYROLEAN FISHERIES LAW 2002. Tiroler Fischereigesetz 2002 - Landesgesetzblatt Nr. 54/2002, § 30, Abs. 1.

UNTERKIRCHER F., 1967. Das Tiroler Fischereibuch Maximilians I. Verlag Styria, Graz, 2 Bände (Faksimileband: 112 pp + 8 Tafeln; Textband: 152 pp).

VERHOEF G.D., AUSTIN C.M., 1999a. Combined effects of temperature and density on the growth and survival of juveniles of the Australian freshwater crayfish, Cherax destructor Clark, Part 1. Aquaculture, 170, 37-47.

VERHOEF G.D., AUSTIN C.M., 1999b. Combined effects of shelter and density on the growth and survival of juveniles of the Australian freshwater crayfish, Cherax destructor Clark, Part 2. Aquaculture, 170, 49-57. 